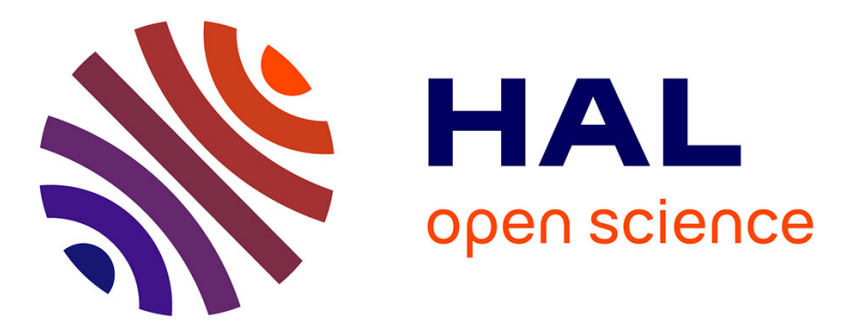

\title{
Improving past sea surface temperature estimates based on planktonic fossil faunas
}

C Waelbroeck, Laurent Labeyrie, Jean-Claude Duplessy, Joel Guiot, Monique Labracherie, H. Leclaire, Josette Duprat

\section{- To cite this version:}

C Waelbroeck, Laurent Labeyrie, Jean-Claude Duplessy, Joel Guiot, Monique Labracherie, et al.. Improving past sea surface temperature estimates based on planktonic fossil faunas. Paleoceanography, 1998, 13 (3), pp.272-283. 10.1029/98PA00071 . hal-01457633

\section{HAL Id: hal-01457633 \\ https://hal.science/hal-01457633}

Submitted on 12 Oct 2020

HAL is a multi-disciplinary open access archive for the deposit and dissemination of scientific research documents, whether they are published or not. The documents may come from teaching and research institutions in France or abroad, or from public or private research centers.
L'archive ouverte pluridisciplinaire HAL, est destinée au dépôt et à la diffusion de documents scientifiques de niveau recherche, publiés ou non, émanant des établissements d'enseignement et de recherche français ou étrangers, des laboratoires publics ou privés. 


\title{
Improving past sea surface temperature estimates based on planktonic fossil faunas
}

\author{
C. Waelbroeck, ${ }^{1}$ L. Labeyrie, ${ }^{1,2}$ J.-C. Duplessy, ${ }^{1}$ J. Guiot, ${ }^{3}$ \\ M. Labracherie, ${ }^{4}$ H. Leclaire, ${ }^{1}$ and J. Duprat ${ }^{4}$
}

Abstract. A new method of past sea surface temperature (SST) reconstruction based on the modern analog technique (Prell, 1985) and on the indirect approach (Bartlein et al., 1986) has been developed: the revised analog method (RAM). Applied to planktonic foraminifera, this technique leads to significant improvements in modern SST reconstruction with respect to former methods: our estimates are characterized by much lower residuals and a better coverage of the observed SST range. Moreover, the error of RAM estimates of past SSTs is lower than that associated with former reconstructions, particularly at middle and high latitudes. In low latitudes, cold season SSTs reconstructed by RAM during glacials are $1^{\circ}$ $3^{\circ} \mathrm{C}$ lower than previously estimated. Our results tend thus to reconcile paleoestimates of glacial temperatures based on planktonic microfossils and on continental data in the tropics.

\section{Introduction}

During the last decade, two methods have been commonly used to assess past sea surface temperatures (SSTs) based on planktonic faunal composition: the Imbrie and Kipp transfer function [Imbrie and Kipp, 1971] and the modern analog technique (MAT) [Hutson, 1979, Prentice, 1980; Overpeck et al., 1985; Prell, 1985]. However, these methods often give different results. One issue is thus to determine which reconstructions are the best and why. On the other hand, SSTs reconstructed by both these methods in low latitudes during the last glacial maximum (LGM) are at most $2^{\circ}-3^{\circ} \mathrm{C}$ cooler than present SSTs [Climate Long-Range Investigation, Mapping, and Prediction (CLIMAP), 1981; Prell, 1985], whereas studies based on continental data reconstruct temperatures $3^{\circ}-9^{\circ} \mathrm{C}$ colder than the current SSTs at those latitudes. For example, reconstructions obtained from pollen records imply a cooling of $3^{\circ}-6^{\circ} \mathrm{C}$ with respect to the present time [Bush and Colinvaux, 1990; Bonnefille et al., 1992], and data on snow lines or tree lines lead to an estimated cooling of $4^{\circ}-9^{\circ} \mathrm{C}$ [Peterson et al., 1979]. Consequently, both the Imbrie and Kipp (I\&K) and MAT methods are suspected of producing biased SSTs in certain cases. Finally, reconstruction and modeling of the past ocean circulation demand an accurate description of surface water temperature and salinity. Salinity can be derived from the planktonic ${ }^{18} \mathrm{O} /{ }^{16} \mathrm{O}$ ratio of planktonic foraminifera if SST is known [Duplessy et al., 1991]. However, the uncertainty of reconstructed salinities rapidly increases with the uncertainty of

\footnotetext{
${ }^{1}$ Laboratoire des Sciences du Climat et de l'Environnement, Laboratoire mixte CNRS-CEA, Domaine du CNRS, Gif-sur-Yvette, France.

${ }^{2}$ Also at Departement des Sciences de la Terre, Unıversité Paris-sud Orsay, Orsay cedex France.

${ }^{3}$ Laboratoire de Botanique Historique et Palynologie, CNRS URA 1152, Marseille, France.

${ }^{4}$ Département de Géologie et Océanographie, CNRS URA 197, Université de Bordeaux I, Talence, France.
}

Copyright 1998 by the American Geophysical Union.

Paper number 98PA00071.

0883-8305/98/98PA-00071 $\$ 12.00$
SSTs. So, in order to be able to detect salinity changes, it is crucial to keep the error associated with SST estimates the lowest possible.

For all these reasons our goal has been to determine why the existing methods give different results and to propose a new method, which minimizes the uncertainty and biases associated with the SST estimates. We first shortly describe the Imbrie and Kipp (I\&K) and MAT methods and the way results obtained with these methods are biased. We then present the revised analog method (RAM), discuss its performance, and give examples of reconstructions obtained by this method.

\section{Biases in Former SST Reconstructions}

A detailed description of the I\&K and MAT methods is given by Imbrie and Kipp [1971] and Prell [1985]. Both methods assume, as do all paleoclimatic reconstruction methods, that the relationship linking the faunal assemblages from a collection of core tops to the environmental conditions measured at the corresponding sites can also describe, the evolution in time of the faunas at a single site in response to changes in the environment or climate.

The I\&K method is based on several additional important hypotheses, which are not all verified in the real ocean. We discuss here the hypotheses that lead to systematic biases in the temperature estimates: (1) the response of each assemblage can be approximated by an equation of the second degree in the independent variables representing the physical parameters of the ecosystem (i.e., SST, salinity, nutrient concentration, primary production, etc.); (2) when several environmental parameters are simultaneously reconstructed, these are assumed to be statistically independent. The method consists in converting the core-top faunal composition into a small number of end-member assemblages by factor analysis and of deriving a regression equation (the transfer function) between these assemblages and the measured environmental variables. The transfer function is then applied to paleosamples to estimate paleoenvironments. The two hypotheses mentioned above warrant the existence of a solution in which each environmental variable is expressed as a function of the end-member assemblages [Imbrie and Kipp, 1971]. Examining the envi- 

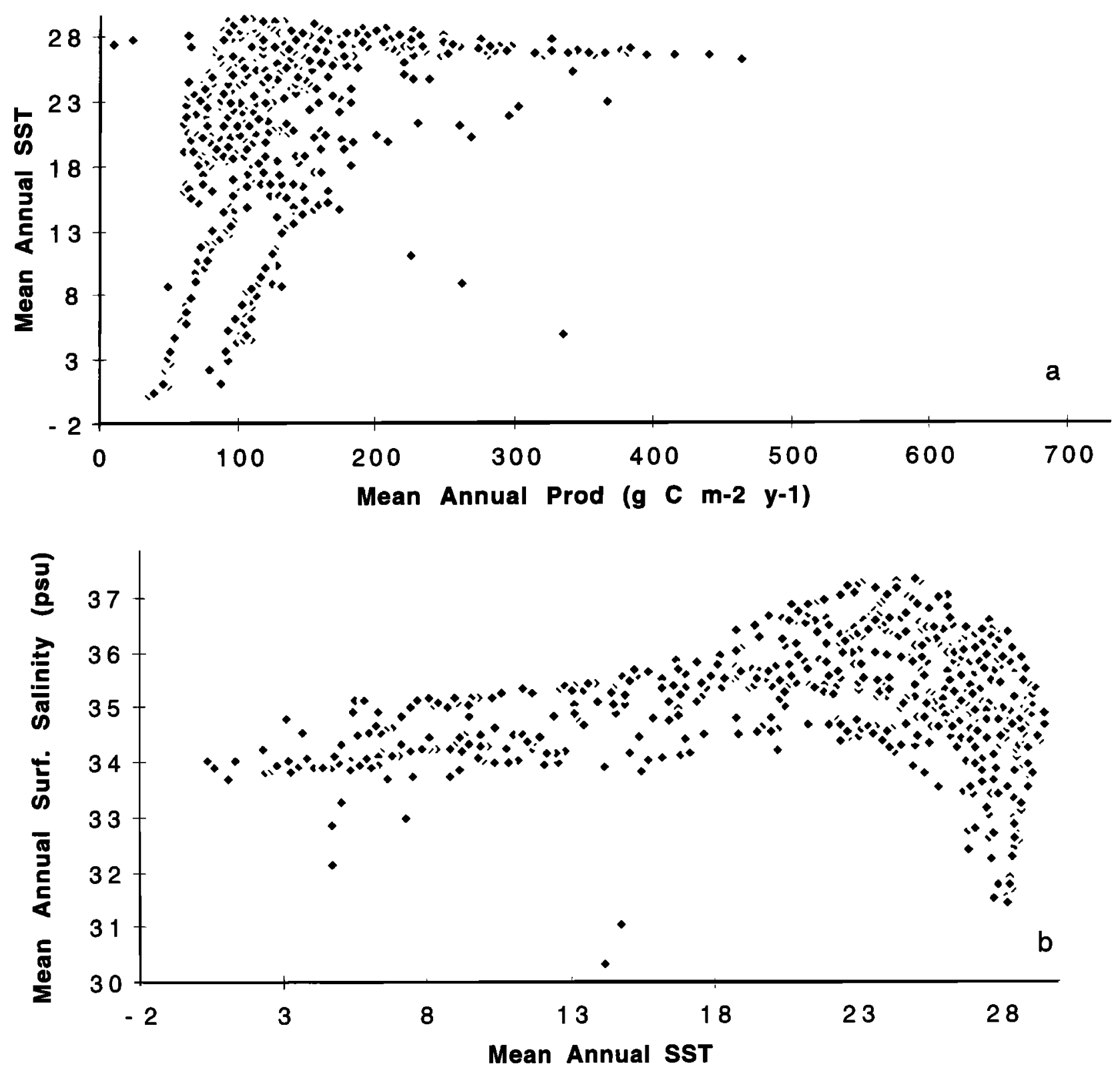

Figure 1. (a) Mean annual sea surface temperature (SST) [Levitus, 1994] versus mean annual primary production [Antoine et al., 1996] and (b) mean annual surface saljnity [Levitus, 1994] versus mean annual SST at the core-top sites of the world database used by Prell [1985].

ronmental parameters values at the sites of the modern database used in the reconstructions, one immediately realizes that some are highly correlated. This is the case, for instance, of SST and primary production, of SST and salinity, of summer SST and winter SST, etc., as is illustrated in Figure 1 for the world database composed of 1145 sites used by Prell [1985]. In those cases, the two hypotheses are not verified, and a relationship defining each environmental variable as a function of the assemblages cannot be properly derived. In other words, the I\&K method is, indeed, used outside its domain of validity. As a matter of fact, the transfer function derived in the I\&K method is only a formulation of the relation between the assemblages and the environmental variables observed for the majority of the database sites and is unable to successfully re- construct past environmental conditions corresponding to faunas which are marginal with respect to the main trends emerging from the modern database. This explains why modern SSTs reconstructed by this method differ so much from measured SSTs in certain sites and, in particular, at high latitudes (Figure 2a).

On the contrary, MAT's only assumption is that the present spatial relations between the faunal composition and the environment can serve as temporal relations at a single site. The method consists in looking in the database for core tops (called "best analogs") which have the "closest" faunal composition to that of the sample, and then averaging the modern values of environmental variables measured at the corresponding core tops sites. In order to do that, a "dissimilarity coeffi- 


\section{COLD SEASON}

(a) $I \& K$

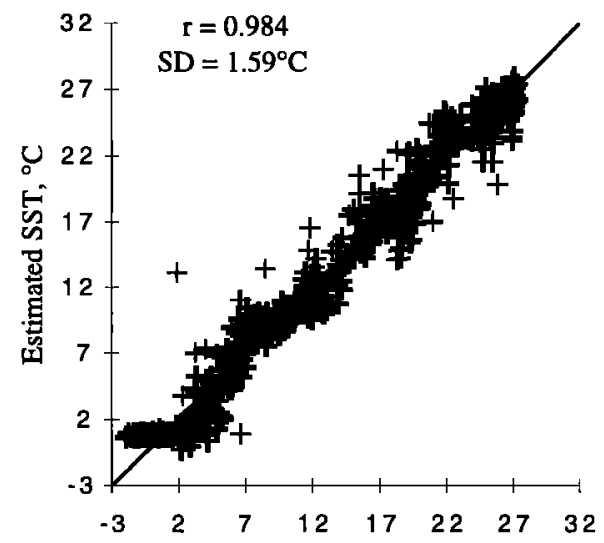

(b) MAT

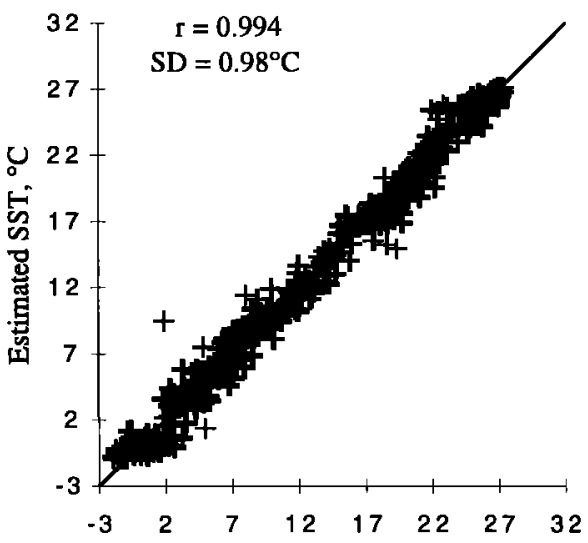

(c) RAM

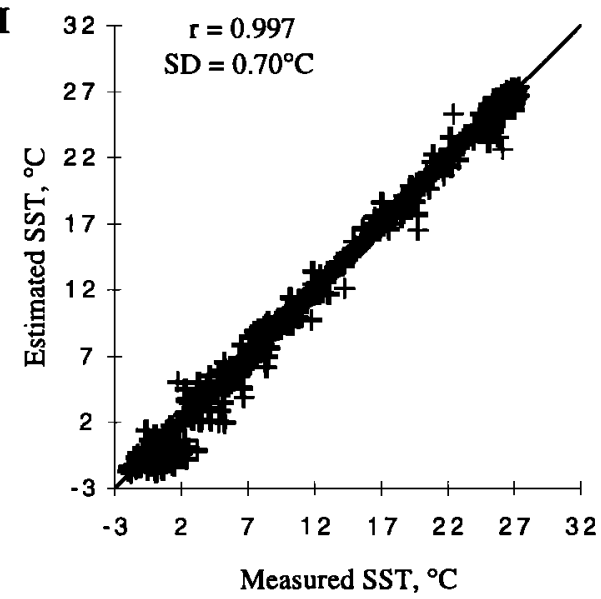

\section{WARM SEASON}
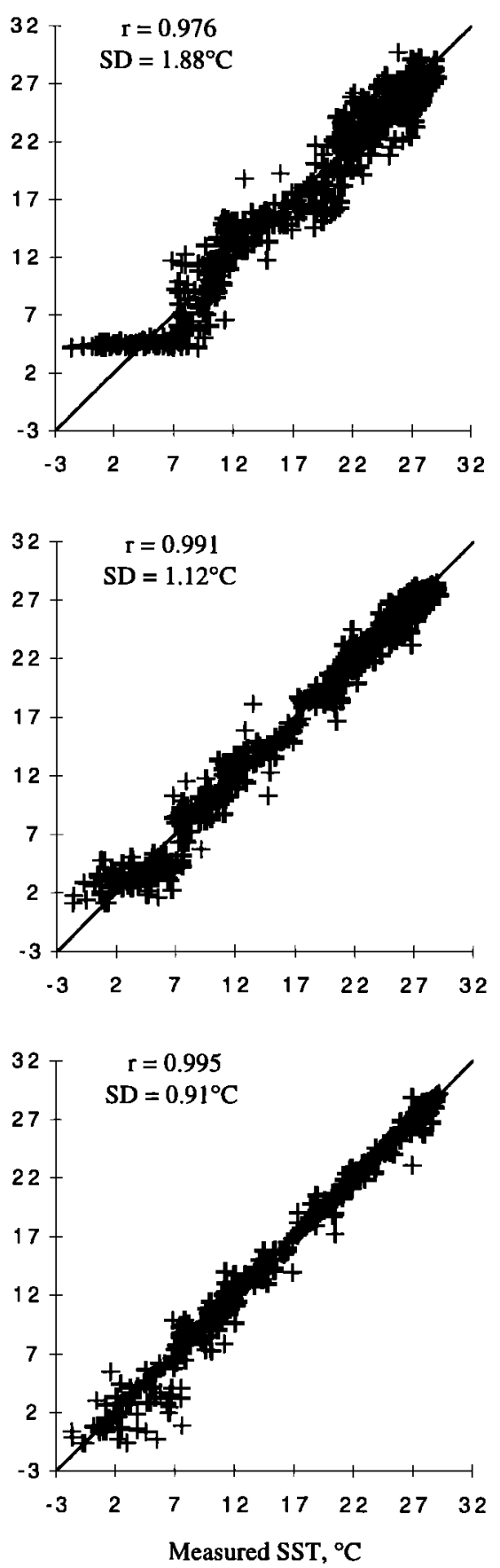

Figure 2. Estimated versus measured SST at the 615 sites of the North Atlantic database for the Imbrie and Kipp transfer function (I\&K), modern analog technique (MAT), and revised analog method (RAM) ( $r$, correlation coefficıent and SD, standard deviation as in Table 1).

cient" is defined which measures how different the faunal compositions of two given samples are. There exist several dissimilarity measures among which the squared chord distance gives the best results according to Prell [1985] and is the most commonly used. We use this dissimilarity measure in the present study also. Although MAT does not suffer from the same limitations as the I\&K method, the procedure used to select the modern analogs induces other limitations. Two criteria are simultaneously applied: (1) only the analogs whose dissimilarity coefficients are lower than a fixed threshold value are retained; (2) a fixed number of best analogs are involved in the averaging leading to the estimation of the environmental con- 
ditions. The first selection criterion is inappropriate to define which modern analogs should be kept or rejected because the value of the dissimilarity coefficient depends on the diversity of the faunas and is intrinsically larger in low latitudes than in high latitudes. Therefore the same threshold value cannot serve in different sites or along the whole length of a given core. The second criterion is also too rigid: the constant number of best analogs selected, $N$, is often either too large or too small, depending on the specific sample studied. If the first few best analogs correspond to a homogeneous type of environmental conditions, a large value of $N$ will unnecessarily degrade the reconstruction by including in the averaging procedure core tops that are quite different from the sample. On the contrary, if a large number of core tops have faunal composition resembling that of the sample, a small value of $N$ could induce large errors in the reconstruction because the averaging would not be sufficient. These bad selection criteria are partly responsible for the poor modern SST reconstructions obtained for the lowest and highest SSTs (Figure 2b). The second main weakness of MAT is the fact that it is sometimes not possible to find satisfactory analogs because of the incomplete coverage of the modern database. Finally, when applied to foraminiferal faunas, the method is unable to reconstruct the temperature gradients in very high latitudes because the fauna becomes monospecific (the only species found is left-coiling Neogloquadrina pachyderma). Note that the SSTs reconstructed by the I\&K method are even less reliable at these latitudes (Figure 2a).

The ability of the I\&K and MAT methods to reconstruct SSTs from sediment trap assemblages has been tested by Ortiz and Mix [1997] who also concluded that temperature biases associated with MAT estimates are smaller than those generated by $I \& K$, even when regional transfer functions are developed. Finally, improved modern SST estimates have been obtained by Pflaumann et al. [1996] with a version of MAT which uses a dissimilarity coefficient based on the squared cosine theta distance and which computes the average of the modern analogs SSTs weighted by the inverse of the geographical distance between the sample and the selected analog core-top locations. Weighting by the inverse geographical distance favors the geographically closest analogs even when there is no reason to suspect the best analogs to be the less distant. Whereas this seems to improve the modern reconstructions, it could considerably degrade the reconstructions of paleoenvironments if fossil fauna migrated along with climate and ocean circulation changes and developed away from their modern centers during certain periods.

\section{The Revised Analog Method}

\subsection{The Method}

The revised analog method (RAM) is based on MAT with the following important changes. We implemented an objective selection criterion of the best analogs, and the indirect approach, also called response surface method, already successfully applied in palynology [Bartlein et al., 1986].

Our selection method assumes that the dissimilarity coefficient permits us to discriminate between different ecological regimes: that is, samples with close dissimilarity values pertain to the same type of fauna, and a large change in dissimilarity indicates a shift from one type of fauna to another. There-

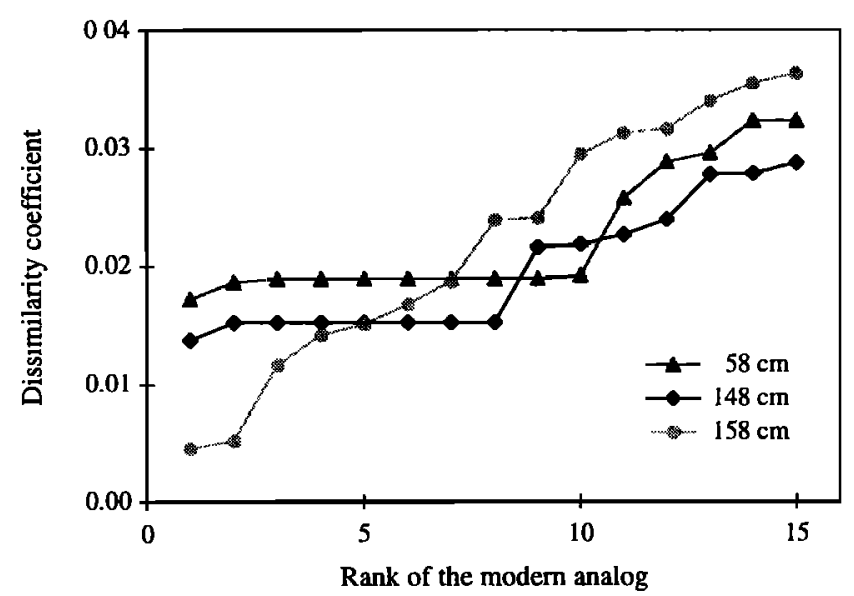

Figure 3. Examples of sharp increases ("jumps") encountered in the dissimilarity coefficients of the first 15 best analogs in three samples from core 90-013-013-P.

fore, for each studied sample, we look for sharp increases (or jumps) in the curve obtained when the dissimilarity coefficient is drawn as a function of the rank of the best analogs selected (Figure 3). We then keep the group of best analogs encountered before the first jump is detected, retaining a minimum of two best analogs. More precisely, we define a "jump" as an increase in dissimilarity larger than a fraction $\alpha$ of the dissimilarity of the last modem analog selected. In cases where no jump is encountered we keep a given number of best analogs $\beta$. The value of $\alpha$ is usually between 0.1 and 0.3 . In this work we take $\beta$ equal to the fixed number of best analogs selected in MAT (presently 10). As shown hereafter, RAM's results are not very sensitive to changes in $\beta$.

The indirect approach consists in remapping the data in the environmental space before searching for analogs. The first step is to build a regular grid in the environmental space, i.e., in the present case, the plane whose axes are the modem warm and cold season SSTs. In contrast to Bartlein et al. [1986], we do not compute a surface representing the dependence of the foraminiferal abundances on the environmental variables but simply compute the foraminiferal abundances at a number of grid nodes of the SST plane. This is done by interpolating the abundances of the database core tops, located within a given radius $R$ centered on the grid node and weighted by their Euclidean distance to this grid node. In that way, interpolation is permitted only between core-top assemblages associated with close SST conditions (SST difference $\leq 2 R$ in both seasons). Accordingly, the remapping procedure generates new data when at least one core top is found within a distance $R$ of the grid node. Two additional parameters are thus introduced by the indirect approach, i.e., the grid step $\gamma$ and the interpolation radius $R$. We obtain good results for $R$ approximately equal to the grid step $\gamma$ (see section 3.3). Note that several different physical variables can be simultaneously interpolated by using adimensional coordinates. In summary, this interpolation procedure allows us to create additional data points which tend to homogenize the SST and faunal abundance coverage of the reference database. Figure 4 shows the Globigerina bulloides abundance before and after remapping in the environmental space for the North Atlantic with $\gamma=0.3^{\circ} \mathrm{C}$ and $R=\gamma$. In this 
a
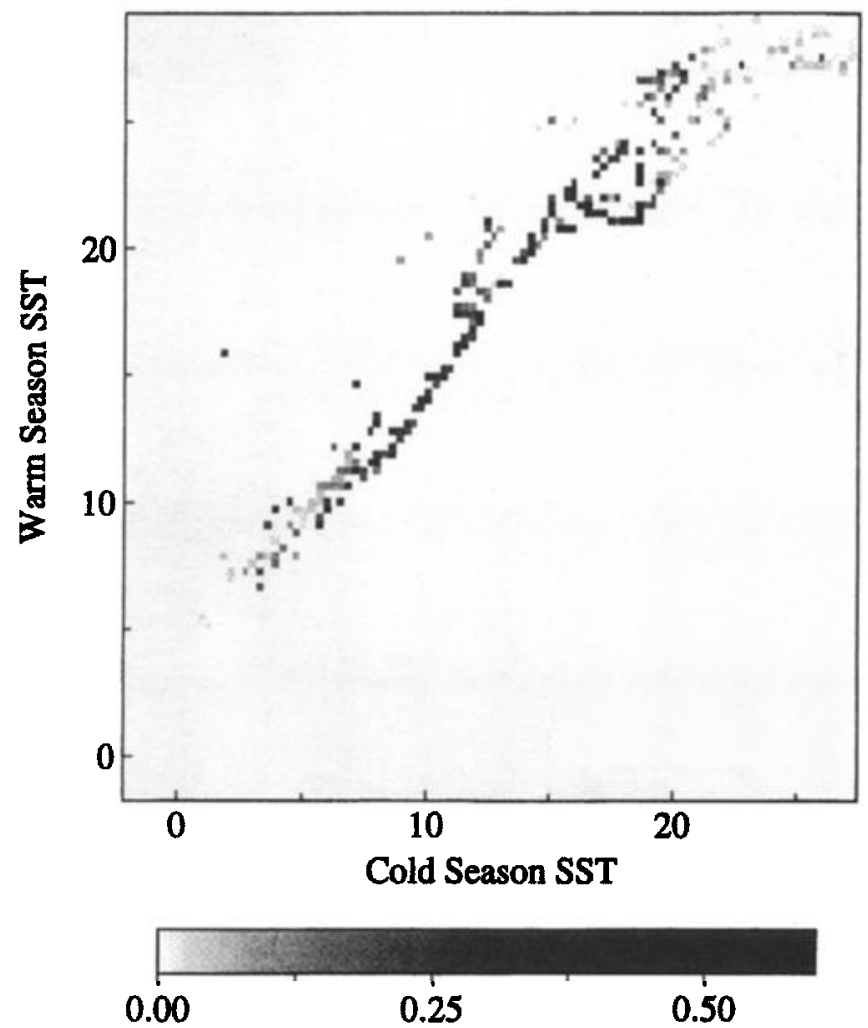

G. bulloides Abundance (0-1) b

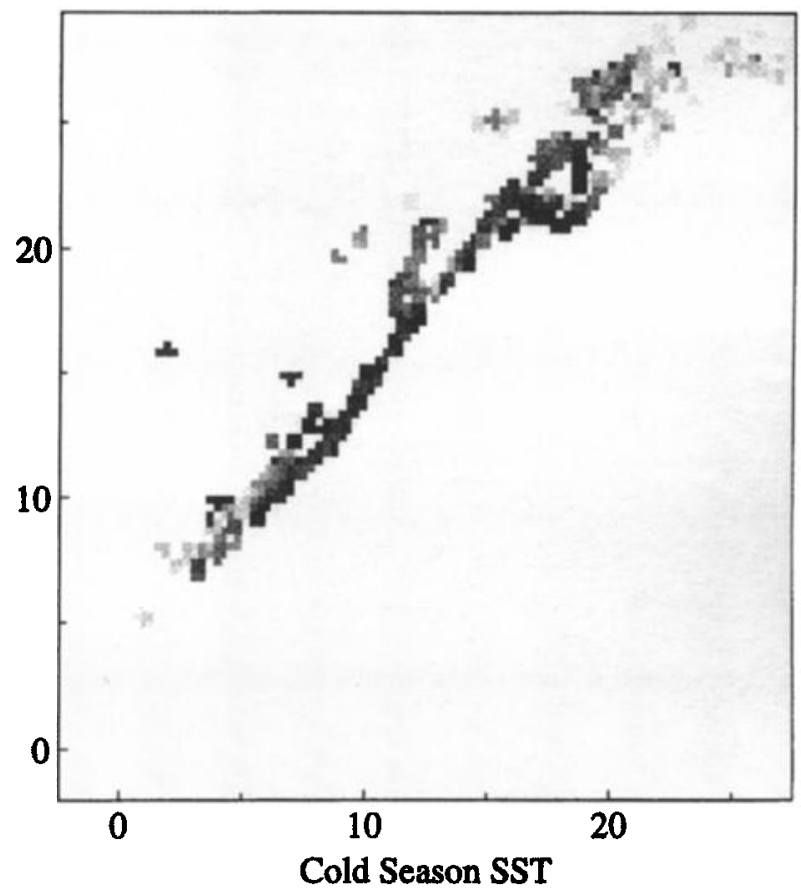

0.00
0.25

0.50

G. bulloides Abundance (0-1)

Figure 4. (a) Globigerina bulloides abundance at the 615 North Atlantic sites. (b) Globigerina bulloides abundance after remapping in the environmental space with $\gamma=0.3^{\circ} \mathrm{C}$ and $\mathrm{R}=\gamma$ (see text). The interpolation procedure creates 839 additional data points.

case the number of additional data points is 839 . One has the option to keep the reference data points together with the newly interpolated data points or to only utilize the interpolated data points in further calculations. In the latter case this leads to a smoothing of the original database which has the advantage of eliminating the fraction of the noise associated with the variability of physical parameters one does not wish to reconstruct. However, the smoothing may erase part of the signal variability, especially if the chosen grid step is large. In the present study we have kept the original data set together with the interpolated assemblages.

\subsection{Performance}

RAM's ability to reconstruct modern SSTs is illustrated in Figure $2 c$ and quantified in Table 1 . These results have been obtained for the I\&K, MAT, and RAM methods using the same database: the North Atlantic database (a subset from the Atlantic database from Pflaumann et al. [1996] consisting of 615 core tops located between $0^{\circ}$ and $80^{\circ} \mathrm{N}$ ) and the corresponding average winter and summer SSTs interpolated from the $1^{\circ} \times 1^{\circ}$ WOA94 data set [Levitus, 1994]. We classed the modern SSTs into cold and warm season groups to correctly take into account low-latitude core-top assemblages. MAT and RAM modem SST reconstructions are obtained by excluding the sample being assessed from the database. The numbers given in Table
1 for Pflaumann et al.'s method are taken from Table 1 of Pflaumann et al. [1996] and correspond to a larger database covering the Eastern North and South Atlantic. MAT and RAM results were obtained by running FORTRAN codes on a Digital workstation Alpha.

RAM gives better results than MAT, which itself gives better results than I\&K. This is marked by higher correlation coefficients between estimated and measured SSTs and by lower standard deviations of the residuals (i.e., differences between estimated and measured SSTs). The improvement is particularly evident at the cold and warm ends of the temperature range (Figure 2). This translates into much higher correlation coefficients between the estimated and measured SSTs over the coldest and warmest temperatures (Table 1) and a better coverage of the observed SST range: the minimum SST reconstructed by RAM is much closer to the minimum measured cold and warm season SSTs than those reconstructed by the other methods (Table 1). The important improvement obtained in reconstructing very cold environments in which the foraminifera assemblages are not completely monospecific is indeed one of the main achievements of the method. The poor estimates given by MAT in that kind of environment result from the fact that there are not many core tops located in the very high latitudes in the reference database. Therefore, when assessing the SST of one of these high-latitude core tops, several modern analogs retained by MAT are more southerly core tops. The average 
Table 1. Comparison of Selected Methods to Reconstruct Sea Surface Temperatures in the Atlantic

\begin{tabular}{|c|c|c|c|c|c|}
\hline Method & $1 \& K$ & MAT & $\begin{array}{c}\text { Pflaumann et al. } \\
\text { [1996] }\end{array}$ & This Study & $\begin{array}{l}\text { Measured SST } \\
\text { [Levitus, 1994] }\end{array}$ \\
\hline $\begin{array}{l}\text { Number of species } \\
\text { Number factors/best analogs } \\
\text { Number of calibration points } \\
\text { Region }\end{array}$ & $\begin{array}{c}35 \\
5 \\
615 \\
\text { North Atlantic }\end{array}$ & $\begin{array}{c}35 \\
10 \\
615 \\
\text { North Atlantic }\end{array}$ & $\begin{array}{c}26 \\
10 \\
738 \\
\text { Eastern North and } \\
\text { South Atlantic }\end{array}$ & $\begin{array}{c}35 \\
\text { computed }(\leq 10) \\
615 \\
\text { North Atlantic }\end{array}$ & \\
\hline $\begin{array}{l}\text { Cold season SSTs }<4^{\circ} \mathrm{C} \\
r \\
\text { SD on the residuals, }{ }^{\circ} \mathrm{C} \\
\text { Minimum SST, }{ }^{\circ} \mathrm{C}\end{array}$ & $\begin{array}{c}0.422 \\
1.81 \\
-0.26(\text { res. }=2.44)\end{array}$ & $\begin{array}{c}0.757 \\
1.28 \\
-0.96(\text { res. }=0.95)\end{array}$ & -1.4 & $\begin{array}{c}0.841 \\
1.05 \\
-1.85 \text { (res. }=0.09)\end{array}$ & -2.00 \\
\hline $\begin{array}{l}\text { Cold season SSTs }>22^{\circ} \mathrm{C} \\
r \\
\text { SD on the residuals, }{ }^{\circ} \mathrm{C} \\
\text { Maximum SST, }{ }^{\circ} \mathrm{C}\end{array}$ & $\begin{array}{c}0.675 \\
1.25 \\
27.45(\text { res. }=0.08)\end{array}$ & $\begin{array}{c}0.842 \\
0.81 \\
26.82 \text { (res. }=0.55 \text { ) }\end{array}$ & 27.2 & $\begin{array}{c}0.917 \\
0.60 \\
26.74 \text { (res. }=0.63)\end{array}$ & 27.37 \\
\hline $\begin{array}{l}\text { Cold season SSTs (all) } \\
r \\
\text { SD on the residuals, }{ }^{\circ} \mathrm{C}\end{array}$ & $\begin{array}{c}0.984 \\
1.59\end{array}$ & $\begin{array}{c}0.994 \\
0.98\end{array}$ & $\begin{array}{l}0.99 \\
0.90\end{array}$ & $\begin{array}{c}0.997 \\
0.70\end{array}$ & \\
\hline $\begin{array}{l}\text { Warm Season SSTs }<8^{\circ} \mathrm{C} \\
r \\
\text { SD on the residuals, }{ }^{\circ} \mathrm{C} \\
\text { Minimum SST, }{ }^{\circ} \mathrm{C}\end{array}$ & $\begin{array}{c}0.481 \\
2.37 \\
+4.13 \text { (res. }=2.89 \text { ) }\end{array}$ & $\begin{array}{c}0.722 \\
1.89 \\
+1.13 \text { (res. }=2.77 \text { ) }\end{array}$ & +0.4 & $\begin{array}{c}0.799 \\
1.79 \\
-0.64 \text { (res.=0.05) }\end{array}$ & -1.64 \\
\hline $\begin{array}{l}\text { Warm Season SSTs }>24^{\circ} \mathrm{C} \\
r \\
\text { SD on the residuals, }{ }^{\circ} \mathrm{C} \\
\text { Maximum SST, }{ }^{\circ} \mathrm{C}\end{array}$ & $\begin{array}{c}0.567 \\
1.31 \\
27.58 \text { (res.=1.55) }\end{array}$ & $\begin{array}{c}0.821 \\
0.75 \\
27.39 \text { (res.=1.74) }\end{array}$ & 28.6 & $\begin{array}{c}0.934 \\
0.45 \\
29.26 \text { (res.=0.13) }\end{array}$ & 29.13 \\
\hline $\begin{array}{l}\text { Warm Season SSTs (all) } \\
r \\
\text { SD on the residuals, }{ }^{\circ} \mathrm{C}\end{array}$ & $\begin{array}{c}0.976 \\
1.88\end{array}$ & $\begin{array}{c}0.991 \\
1.12\end{array}$ & $\begin{array}{l}0.99 \\
0.96\end{array}$ & $\begin{array}{l}0.995 \\
0.91\end{array}$ & \\
\hline
\end{tabular}

The abbreviations are defined as follows: I\&K, Imbrie and Kipp transfer function; MAT, modem analog technique; SST, sea surface temperature; $r$, correlation coefficient equals Cov (estimates, measurements)/(SD estimates)(SD measurements); SD, standard deviation; and res., residual equals estimated SST minus measured SST.

SST computed on the 10 modern analogs is thus systematically too warm, and the associated standard deviation (SD) is too large. By optimizing the modern analog selection and adding interpolated data around the high-latitude core-tops of the reference data set our method brings an adapted answer to this problem.

The SD of the residuals is a measure of the reconstructed SSTs' error envelope. This error results, in part, from the error on the foraminiferal species counts and, in part, from the sta- tistical nature of the method itself. The respective importance of these two sources of errors is difficult to assess. In order to lower the counting error on polar samples (containing dominant left-coiling $N$. pachyderma), Pflaumann et al. [1996] increased the number of specimens counted per sample from 300 to 2500 . However, the fact that our method leads to a clear decrease in the error envelope with respect to Pflaumann et al.'s method shows that the statistical method itself is responsible for a large portion of the error envelope.

Table 2. Sensitivity Analysis

\begin{tabular}{|c|c|c|c|c|c|c|c|c|}
\hline & \multicolumn{4}{|c|}{ Parameters } & \multicolumn{2}{|c|}{ Winter Estimates } & \multicolumn{2}{|c|}{ Summer Estimates } \\
\hline & $\alpha$ & $\beta$ & $\gamma,{ }^{\circ} \mathrm{C}$ & $R$ & $r$ & SD & $r$ & SD \\
\hline Control run & 0.1 & 10 & 0.3 & 0.3 & 0.997 & 0.70 & 0.995 & 0.91 \\
\hline Sensitivity runs & $\begin{array}{c}\text { control } \\
\text { control } \\
\text { control } \\
0.2 \\
\text { control }\end{array}$ & $\begin{array}{c}\text { control } \\
\text { control } \\
\text { control } \\
\text { control } \\
15\end{array}$ & $\begin{array}{c}\text { control } \\
\text { control } \\
0.45 \\
\text { control } \\
\text { control }\end{array}$ & $\begin{array}{c}-50 \% \\
+50 \% \\
\text { control } \\
\text { control } \\
\text { control }\end{array}$ & $\begin{array}{l}0.995 \\
0.997 \\
0.996 \\
0.997 \\
0.997\end{array}$ & $\begin{array}{l}0.91 \\
0.73 \\
0.84 \\
0.71 \\
0.71\end{array}$ & $\begin{array}{l}0.992 \\
0.994 \\
0.992 \\
0.994 \\
0.995\end{array}$ & $\begin{array}{l}1.08 \\
0.98 \\
1.08 \\
0.96 \\
0.91\end{array}$ \\
\hline Indirect approach alone & _ & control & control & control & 0.995 & 0.86 & 0.992 & 1.09 \\
\hline
\end{tabular}




\subsection{Sensitivity Analysis}

We evaluated the sensitivity of our modem SST reconstructions to changes in the method's parameters (Table 2). The quality of the reconstructions is more sensitive to changes in the interpolation radius $R$ than to changes in the grid step $\gamma$ and show less sensitivity to the threshold value of the dissimilarity increase rate $\alpha$. The maximum number of best analogs, $\beta$, has almost no impact on the results. Implementing the indirect approach alone while keeping MAT's selection criteria of the best analogs considerably degrades the results (Table 2): the dispersion increases over the entire temperature range, while the biases occurring at high and low temperatures in MAT estimates tend to reappear. The new selection method and the interpolation procedure contribute in similar proportions to improving the estimates.

\section{Applications to Fossil Faunas}

We have applied RAM to several cores from the Atlantic Ocean (Figure 5 and Table 3 ) in order to examine the impact of the method on paleo-SST reconstructions. On one hand, we have chosen middle-latitude to high-latitude cores with good Holocene records in order to be able to compare core-top SST estimates with modern measured SSTs. Among those the northernmost core has the advantage of allowing us to test RAM's reconstruction of low paleo-SSTs with respect to MAT during the Younger Dryas event. On the other hand, we have focused on low latitudes and checked whether RAM reconstructions during glacials differ from previous estimates or not.

\subsection{Data and Methods}

The planktonic foraminiferal species distribution of core CH 69-09 was determined at Laboratoire des Sciences du Climat et de l'Environnement (LSCE) (Gif), on the basis of counts of at least 300 individuals per level. Planktonic foraminifera of core 90-013-013-P were counted at Département de Géologie et Océanographie (DGO) (Bordeaux). Planktonic (or benthic, when available) ${ }^{18} \mathrm{O} /{ }^{16} \mathrm{O}$ ratios as a function of depth as well as the main isotopic stages are reported in Figures 6-10. The ${ }^{18} \mathrm{O} /{ }^{16} \mathrm{O}$ ratio of planktonic and benthic foraminifera is expressed as $\delta^{18} \mathrm{O}$ in per mil versus Pee Dee belemnite (PDB). The $\delta^{18} \mathrm{O}$ of $G$. bulloides in core $\mathrm{CH}$ 69-09 was measured at LSCE on a Finnigan MAT251 mass spectrometer. The mean external reproducibility $(1 \sigma)$ of carbonate standards is \pm $0.05 \%$. The $\delta^{18} \mathrm{O}$ data are calibrated with respect to National Bureau of Standards NBS19 [Hut, 1987; Coplen, 1988]. The other $\delta^{18} \mathrm{O}$ records and planktonic foraminiferal distributions used in the present study were previously published (Table 3 ).

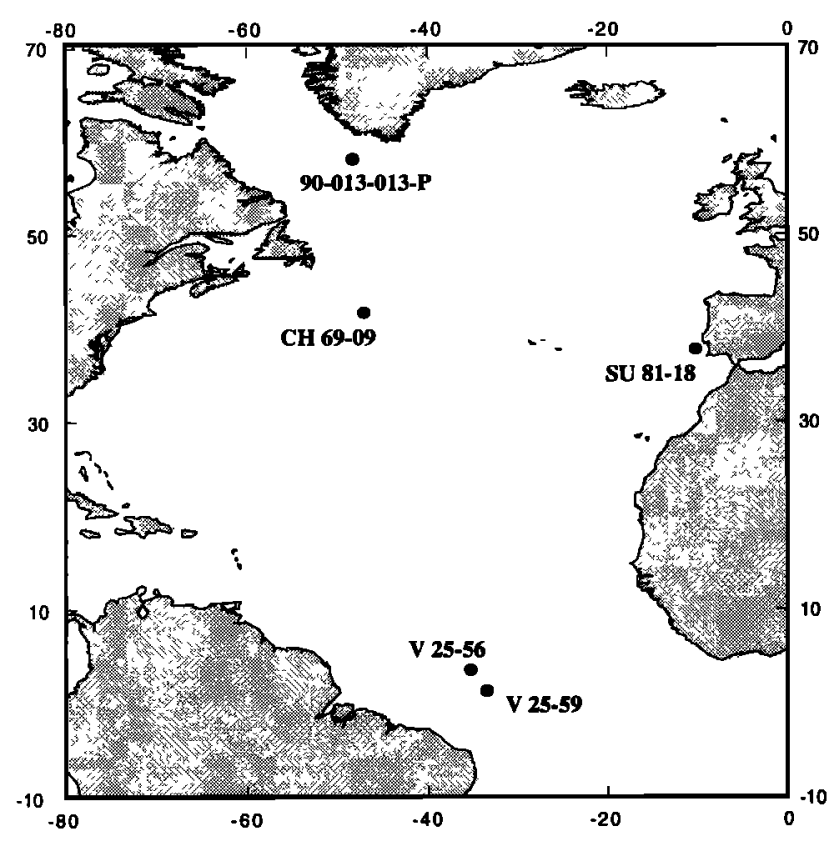

For each core we have reconstructed SSTs on the basis of planktonic foraminiferal abundances both by MAT and RAM methods. In middle-latitude cores, cold and warm season SSTs were evaluated using the same core-top and modern SST database as in section 3 . In low latitudes we used an extended coretop database consisting of the world database of Prell [1985], 45 additional core-tops from the Indian Ocean [Cayre et al., 1998], and the North Atlantic database described above. This enlarged world database comprises 1582 core-tops. The modern hydrological data are the measured mean seasonal SSTs [Levitus, 1994] at the corresponding 1582 sites classed into cold and warm season groups.

For each level the error on the SST estimate is defined as the standard deviation on the set of SSTs corresponding to the selected best analogs, as in the MAT technique [Prell, 1985]. Note that this definition of the error of a given sample estimate is conservative since the reconstructed SST also depends on the error of foraminiferal counts and on the set of parameters used in the reconstruction method. The average errors on RAM and MAT estimates over the total length of each core are reported in Table 4. The error of RAM reconstructions is always lower than that associated with MAT estimates since the selection of modern analogs is optimized in RAM and the standard deviation on the corresponding set of SSTs is thus re-

Table 3. Core Coordinates and Sources of Data

\begin{tabular}{lcccll}
\hline Core & Depth, $\mathrm{m}$ & Latitude, $\mathrm{N}$ & Longitude, W & \multicolumn{1}{c}{ Data } & Reference \\
\hline SU 81-18 & 3135 & $37^{\circ} 46^{\prime}$ & $10^{\circ} 11^{\prime}$ & $\delta^{18}$ 0 (benthic), SST (foraminiferal) & Duplessy et al. [1992] \\
CH 69-09 & 4100 & $41^{\circ} 45^{\prime}$ & $47^{\circ} 21^{\prime}$ & $\delta^{18} 0$ (planktonic), SST (foramınıferal) & This study \\
90-013-013-P & 3380 & $58^{\circ} 13^{\prime}$ & $48^{\circ} 22^{\prime}$ & $\delta^{18} 0$ (planktonic) & Hillaire-Marcel et al. [1994] \\
& & & & SST (foraminiferal) & This study \\
V 25-59 & 3824 & $01^{\circ} 22^{\prime}$ & $33^{\circ} 29^{\prime}$ & $\delta^{18}$ (benthic), SST (foraminiferal) & Mix and Ruddıman [1985] \\
V 25-56 & 3512 & $03^{\circ} 33^{\prime}$ & $35^{\circ} 14^{\prime}$ & $\delta^{18} 0$ (planktonic), SST (foraminiferal) & Mix and Fairbanks [1985] \\
\hline
\end{tabular}


Table 4. Average Error of SST Reconstructions and Resulting Error of Salinity Estimates

\begin{tabular}{|c|c|c|c|c|c|c|}
\hline \multirow[t]{2}{*}{ Core } & \multicolumn{2}{|c|}{$\begin{array}{l}\text { Cold Season SST, } \\
\text { average } S D,{ }^{\circ} \mathrm{C}\end{array}$} & \multicolumn{2}{|c|}{$\begin{array}{l}\text { Warm Season SST, } \\
\text { average SD, }{ }^{\circ} \mathrm{C}\end{array}$} & \multicolumn{2}{|c|}{ Resulting Error of Salinities ${ }^{a}$} \\
\hline & MAT & This study & MAT & This study & MAT & This study \\
\hline SU 81-18 & 1.29 & 0.75 & 1.67 & 0.98 & 0.76 & 0.45 \\
\hline CH 69-09 & 1.83 & 1.49 & 2.70 & 1.87 & 1.23 & 0.85 \\
\hline $90-013-013-P$ & 1.21 & 0.34 & 1.47 & 0.41 & 0.67 & 0.19 \\
\hline V $25-59$ & 1.46 & 0.96 & 0.88 & 0.82 & 0.40 & 0.37 \\
\hline V 25-56 & 1.30 & 1.18 & 0.66 & 0.61 & 0.30 & 0.28 \\
\hline
\end{tabular}

${ }^{a}$ Using Duplessy et al.'s [1991] recontruction and the present-day relatıonship between salinity and seawater $\delta^{18} 0$.

duced. The gain is, however, more important at middle and high latitudes than at low latitudes (e.g., the error is reduced by more than $70 \%$ in core $90-013-013-P$ ). This is due to the fact that because of the greater faunal diversity at low latitudes, dissimilarity coefficients are larger and tend to increase more continuously (i.e., jumps are rarely detected, and the number of selected modern analogs is larger). Therefore the use of RAM leads to an important lowering of the error on salinity estimates in middle and high latitudes (Table 4).

The error associated with MAT reconstructions is so large that it is very often greater than the difference between MAT and RAM estimates. Hereafter, we analyze differences in SST reconstructions when the difference obtained for several consecutive levels is larger than the error associated with RAM SST estimates for these levels.

\subsection{Middle Latitudes}

4.2.1. SU 81-18 $\left(37^{\circ} 46^{\prime} \mathrm{N}, 1^{\circ} 11^{\prime} \mathrm{W}\right)$. The SSTs reconstructed by RAM for core SU 81-18 surface samples are practically identical to the measured cold and warm season SSTs, whereas MAT estimates are underestimated by $\sim 1^{\circ} \mathrm{C}$ in both seasons (Figure 6). This is explained by the fact that all the best analogs selected by RAM are interpolated data points resulting from the remapping procedure. In the present case they compensate for the lack of core-tops in the reference database, with faunas and SSTs similar to those of core SU 81-18. Because the best analogs selected by RAM down core are also mainly interpolated data points, the other discrepancies between RAM and MAT estimates encountered along the core are likely to reflect incorrect MAT estimates too. In particular,

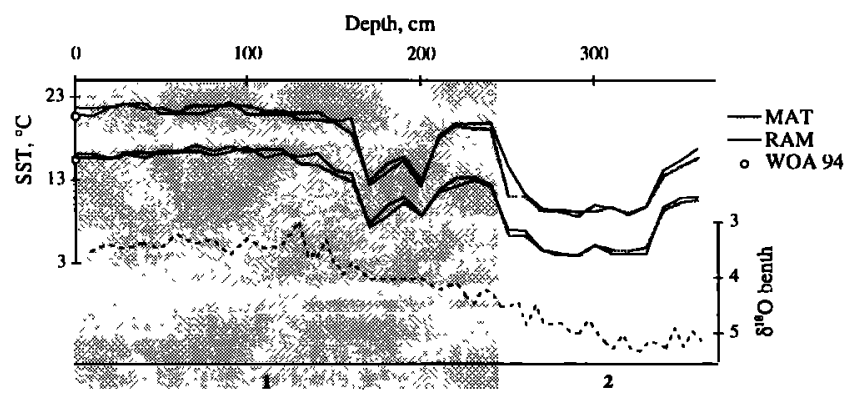

Figure 6. SST signals reconstructed by MAT and RAM, and benthic $\delta^{18} \mathrm{O}$ versus depth in core SU 81-18 $\left(37^{\circ} 46^{\prime} \mathrm{N}, 10^{\circ} 11^{\prime} \mathrm{W}\right)$. Modern SSTs from the World Ocean Atlas 1994 (WOA 94) [Levttus, 1994] are denoted by open circles. this is the case of the SSTs reconstructed by RAM at the beginning of the Holocene $(120-160 \mathrm{~cm})$, which are $\sim 1^{\circ} \mathrm{C}$ warmer than those estimated by MAT. The RAM summer SST signal does, indeed, exhibit significant variations during the Holocene, which did not appear in previous SST reconstructions because of the large error associated with these estimates. For instance, warm episodes can now be identified around 30 and 90 $\mathrm{cm}$, corresponding to accelerator mass spectrometry (AMS) ${ }^{14} \mathrm{C}$ ages given by Bard et al. [1987], of 1.4 and $5.2 \mathrm{ka}$, respectively.

4.2. 2. CH69-09 $\left(41^{\circ} 45^{\prime} \mathrm{N}, 47^{\circ} 21^{\prime} \mathrm{W}\right)$. We find the same SST pattern in this core as in core SU81-18, but considerably amplified (Figure 7). The core-top SST reconstructed by MAT is $-2^{\circ} \mathrm{C}$ too cold in winter and $2.5^{\circ} \mathrm{C}$ too cold in summer. In this case, RAM's excellent reconstruction results from the use of the larger and more homogenous database obtained by interpolation and from the optimized selection of modern analogs. For the first two levels, RAM retains 4 and 2 best analogs, respectively, instead of the 10 best analogs kept by MAT. Because core $\mathrm{CH}$ 69-09 is located along the modern Gulf Stream path, its modern foraminiferal assemblage has the distinct feature of comprising species living in the warm waters of the Gulf Stream together with species living in the underlying colder waters. Our results demonstrate that in contrast to MAT, RAM correctly reconstructs SST in this particular hydrological setting. RAM is, indeed, able to restrict the selection of best analogs to core-tops located along the Gulf Stream path, whereas MAT retains 10 modern analogs in any case. RAM estimates in the rest of the core are also characterized by either a reduced number of selected best analogs or a large proportion of interpolated best analogs. Therefore it is not surprising that RAM reconstructions significantly differ from MAT estimates in many other sections of the core. For instance, the SSTs we reconstruct at the beginning of the Holocene are $2^{\circ}-5^{\circ} \mathrm{C}$ warmer in both seasons than those estimated by MAT. In long sections of stage 5 our summer SST estimates are also significantly higher than MAT estimates. In particular, SSTs remain high at each new increase in ice volume, as already noted by Ruddiman and McIntyre [1984] in the North Atlantic.

However, the very high summer SSTs reconstructed by RAM in many portions of the core, including the core-top, seem not to be imprinted in the $G$. bulloides isotopic record. In fact, the temperature of deposition of calcite derived from the core-top $G$. bulloides $\delta^{18} \mathrm{O}$ and from the measured modern salinity (using the paleotemperature equation) is $12.6^{\circ} \mathrm{C}$, whereas the 

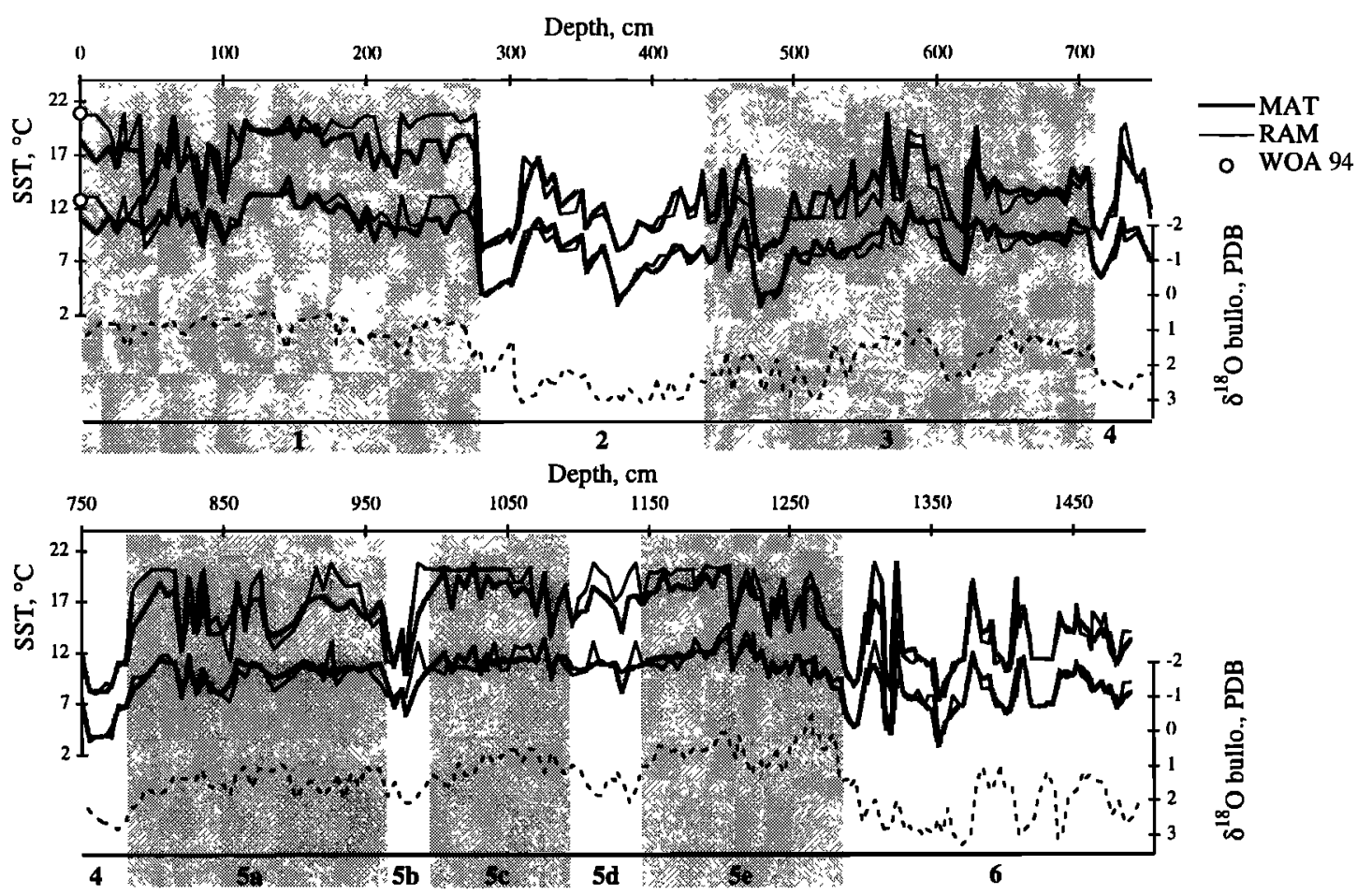

Figure 7. SST reconstruction and planktonic $\delta^{18} \mathrm{O}$ versus depth in core $\mathrm{CH} 69-09\left(41^{\circ} 45^{\prime} \mathrm{N}, 47^{\circ} 21^{\prime} \mathrm{W}\right.$ ) (open circles are as in Figure 6).

measured modem SST is $20.9^{\circ} \mathrm{C}$ [Levitus, 1994] (RAM estimate is $20.8^{\circ} \pm 0.25^{\circ} \mathrm{C}$ ). This can be explained by the fact that $G$. bulloides's preferred habitat is waters between $5^{\circ}$ and $10^{\circ}$ to $18^{\circ} \mathrm{C}$ [Bé, 1977]. As a result, this species tends to live in deeper waters when SST increases beyond the upper limit of its temperature range and does therefore not record SSTs above this limit. Temperature and salinity conditions, consistent with the $G$. bulloides $\delta^{18} \mathrm{O}$ measured in the core-top sample are, in fact, encountered between 50 and $100 \mathrm{~m}$ water depth at the core site (temperature $\approx 13^{\circ}-14^{\circ} \mathrm{C}$ and salinity $\approx 35.5$ ) [Levitus, 1994].

Finally, in the coldest section of the Holocene record (from $\sim 45$ to $100 \mathrm{~cm}$ ) our SST estimates are in agreement with MAT estimates. Therefore, in the present case, the large temperature oscillations occurring during the Holocene appear to be even larger than previously thought. We suggest that these temperature oscillations could be caused by latitudinal drifts of the Gulf Stream track.

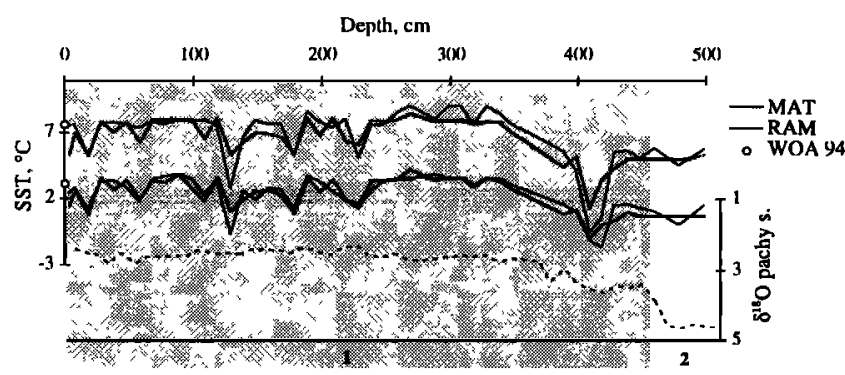

Figure 8. SST reconstruction and planktonic $\delta^{18} \mathrm{O}$ versus depth in core 90-013-013-P $\left(58^{\circ} 13^{\prime} \mathrm{N}, 48^{\circ} 22^{\prime} \mathrm{W}\right.$ ) (open circles are as in Figure 6).
4.2.3. 90-013-013.P $\left(58^{\circ} 13^{\prime} \mathrm{N}, 4^{\circ} 22^{\prime} \mathrm{W}\right)$. In this core we obtain important differences between RAM and MAT estimates in summer as well as some smaller differences in winter (Figure 8). RAM reconstructions of the core-top samples are again much closer to measured SSTs than MAT estimates, as a result of the remapping and optimized selection of modern analogs (two modern analogs retained for the core-top sample). As in core CH 69-09, warm periods appear to be warmer than estimated by MAT. This is particularly evident for the beginning of the Holocene $(250-390 \mathrm{~cm})$ and the Bölling-Alleröd episode $(420-450 \mathrm{~cm})$ where the difference in SST estimates reaches $2^{\circ} \mathrm{C}$. Interestingly, in contrast to the signal reconstructed in $\mathrm{CH}$ 69-09, RAM estimates during cold periods are much colder than MAT estimates. This points out MAT's incapacity to reconstruct SSTs $<+1.1^{\circ} \mathrm{C}$ in summer and $<-1^{\circ} \mathrm{C}$ in winter. The SSTs estimated by RAM during the Younger Dryas (YD) are colder than MAT estimates by $\sim 1^{\circ} \mathrm{C}$ in winter and $2.5^{\circ} \mathrm{C}$ in summer. As a result, the warming marking the transition from the YD to the Holocene appears to be $\sim 4^{\circ} \mathrm{C}$ greater than previously estimated.

In cores $\mathrm{CH}$ 69-09 and 90-013-013-P our results confirm that SSTs have been highly variable during the Holocene. Moreover, in core SU 81-18 RAM reconstruction reveals that SSTs have also significantly varied during that period. Therefore, in all three cores examined here, RAM estimates indicate that SSTs have not been stable throughout the Holocene.

\subsection{Low Latitudes}

In the two cores examined at low latitudes, cold season SSTs exhibit a much larger low-frequency variability (periods $\geq 20$ kyr) than warm season SSTs. In this respect our results confirm 


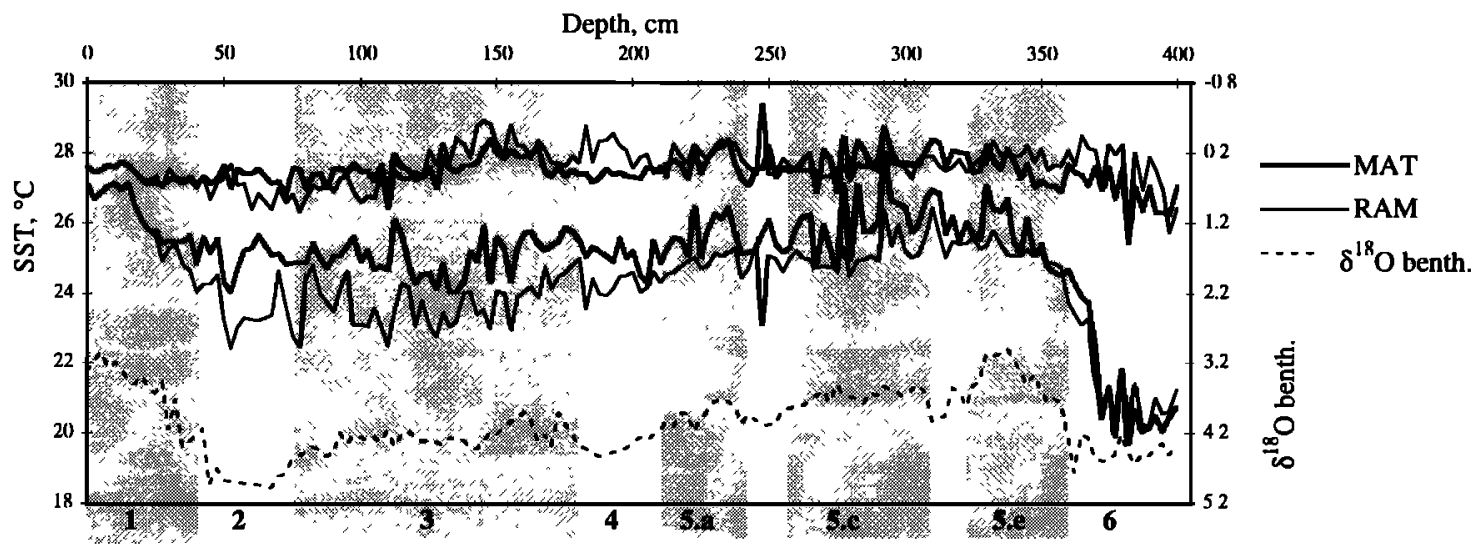

Figure 9. SST reconstruction and benthic $\delta^{18} \mathrm{O}$ versus depth in core $\mathrm{V} 25-59\left(01^{\circ} 22^{\prime} \mathrm{N}, 33^{\circ} 29^{\prime} \mathrm{W}\right)$

previous SST reconstructions in the equatorial Atlantic [e.g., Mclntyre et al., 1989]. However, whereas RAM and MAT reconstructions of the warm SST signal are in good agreement, we obtain large discrepancies in reconstructed cold season SSTs in several sections of the cores. For these levels an important fraction of the modern analogs selected by RAM are interpolated data points.

4.3.1. V 25-59 $\left(01^{\circ} 22^{\prime} \mathrm{N}, 3^{\circ} 29^{\prime} \mathrm{W}\right)$. Cold season SSTs reconstructed by RAM during the last glacial are $1^{\circ}-3^{\circ} \mathrm{C}$ cooler than those obtained by MAT (Figure 9 ). Therefore our estimate of the deglacial warming experienced during the cold season at this site is $\sim 4^{\circ} \mathrm{C}$, in agreement with continental data [e.g., Bush and Colinvaux, 1990]. McIntyre et al. [1989] have reconstructed SSTs in this core by the I\&K method and obtained a signal similar to that reconstructed by MAT. They obtained a deglacial warming of $-2^{\circ} \mathrm{C}$ at the stage $2-1$ transition and $4.5^{\circ} \mathrm{C}$ at the stage $6-5$ transition, resulting in an unexplained contrast between the two last climatic cycles. These authors concluded that the western equatorial Atlantic has been characterized by minimal variation in surface hydrology during the entire last climatic cycle. Conversely, our results show that both the two last climatic cycles experienced important coolings during glacials. Therefore we suggest that the very large difference previously found between the two last glacialinterglacial transitions is, at least partly, an artefact of the reconstruction method.
4.3.2. V 25-56 (0333'S, 35'14'W). Here, also, we obtain lower cold season SSTs during glacials than previously estimated (Figure 10). In particular, cold season SSTs are $\sim 2^{\circ} \mathrm{C}$ cooler during isotopic stage 4 and $1^{\circ}-2^{\circ} \mathrm{C}$ cooler during stage 6. Note that the cold season SST signal reconstructed by MAT during stage 6 is very noisy whereas our reconstruction exhibits a clear shift in temperature from the end of isotopic stage 6 to stage $5 \mathrm{e}$.

In summary, cold season SSTs reconstructed by RAM in the equatorial Atlantic during glacials are $1^{\circ}-3^{\circ} \mathrm{C}$ lower than MAT estimates. A survey of the continental records of environmental conditions at the LGM encompassing palynological and paleobotanical evidences, data on former snow lines, and periglacial features shows that mean annual temperatures were $4^{\circ}-9^{\circ} \mathrm{C}$ colder than present in the $10^{\circ} \mathrm{S}-10^{\circ} \mathrm{N}$ latitudinal band in Africa and South America [Peterson et al., 1979]. More recently, a temperature decrease of $4^{\circ}-6^{\circ} \mathrm{C}$ with respect to the present time has been inferred from pollen records from lowland Panama for the LGM [Bush and Colinvaux, 1990]. In equatorial Africa a temperature decrease of $3 \pm 1.9^{\circ} \mathrm{C}$ has been reconstructed from a pollen sequence [Bonnefille et al., 1992]. Our results tend thus to reconcile studies based on planktonic microfossils and on continental data.

Our reconstructions can also be compared to SSTs based on the unsaturation ratios of long chain alkenones produced by phytoplankton ( $U_{37}^{K}$ index). This method produces a single

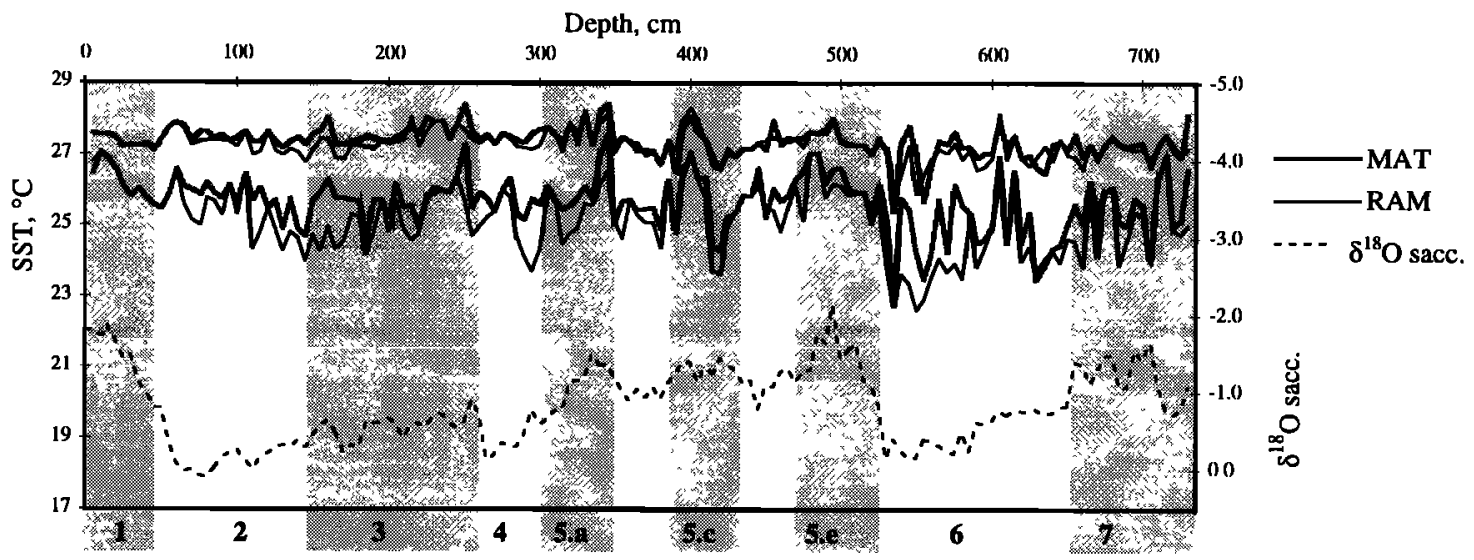

Figure 10. SST reconstruction and planktonic $\delta^{18} \mathrm{O}$ versus depth in core V 25-56 (03 $\left.33^{\circ} \mathrm{S}, 35^{\circ} 14^{\prime} \mathrm{W}\right)$ 
SST estimate which can be interpreted as the annual average, summer, or winter SST, depending on the calibration equation used [Rosell-Melé et al., 1995]. A cooling of only $1.8^{\circ} \mathrm{C}$ has been estimated by this method in core $12 \mathrm{PC} 51\left(0^{\circ} 0^{\prime} \mathrm{N}\right.$, $22^{\circ} 59^{\prime} \mathrm{W}$ ), whereas warm season MAT estimates in the same core imply a cooling of $3.8^{\circ} \mathrm{C}$ [Sikes and Keigwin, 1994]. However, several $\boldsymbol{U}_{37}^{K}$ records in the east equatorial Atlantic show glacial to interglacial differences of $-3.5^{\circ} \mathrm{C}$ in annual mean SST, which is $-1.5^{\circ} \mathrm{C}$ greater than the difference estimated by CLIMAP [Schneider et al., 1995]. Also, spring SST derived from the $U_{37}^{K}$ record of Ocean Drilling Program core $658\left(20^{\circ} 45^{\prime} \mathrm{N}, 18^{\circ} 35^{\prime} \mathrm{W}\right)$ exhibits coolings of $\sim 3^{\circ}, 5^{\circ}$, and $6^{\circ} \mathrm{C}$ for glacial stages 2,6, and 10, respectively [Eglinton et al., 1992]. The latter two studies tend thus to support our results.

\section{Conclusions}

We have discussed the main differences between the I\&K and MAT methods and shown that MAT estimates are intrinsically less biased than I\&K estimates. A new method of past SST reconstructions based on MAT and on the indirect approach has been developed: the revised analog method (RAM). Our results demonstrate that this method leads to significant improvements of the reconstructed modem SSTs, marked by reduced residuals over the entire SST range. The improvement is particularly important for low summer and winter SSTs, the minimum SSTs estimated by RAM reaching $-1.85^{\circ} \mathrm{C}$ in winter and $0.64^{\circ} \mathrm{C}$ in summer, whereas minimum SSTs reconstructed by former methods were overestimated by $0.6^{\circ}-1.7^{\circ} \mathrm{C}$ in winter and $2^{\circ}-5.8^{\circ} \mathrm{C}$ in summer. The correlation between reconstructed and measured SSTs is significantly closer to 1 for high temperatures too.

We have applied this new technique to several cores retrieved in the Atlantic from low and middle latitudes. In cores where the surface samples have been preserved, core-top SSTs estimated by RAM are practically equal to measured SSTs whereas MAT estimates are off by $1^{\circ}-2.5^{\circ} \mathrm{C}$. RAM's excellent reconstruction results from the combination of the larger and more homogeneous database obtained by the remapping procedure and of the optimized selection of modern analogs. Our results demonstrate that RAM successfully reconstructs modern SSTs in hydrological settings where former methods gave poor results, such as the environment characterizing the Gulf Stream path. On the other hand, our estimates of the SST during the Younger Dryas in core 90-013-013-P of the Labrador Sea reach $-0.6^{\circ} \mathrm{C}$ in summer and $-1.7^{\circ} \mathrm{C}$ in winter, whereas MAT estimates remain above $+1.3^{\circ} \mathrm{C}$ in summer and $-1^{\circ} \mathrm{C}$ in winter. This illustrates MAT's incapacity to reconstruct cold paleoenvironments, as already suggested by the poor correlation obtained between cold measured SST and MAT modern SST estimates (Figure 2). In low latitudes, cold season SSTs reconstructed by RAM during glacials are $1^{\circ}-3^{\circ} \mathrm{C}$ cooler than those estimated by MAT. These results tend to reconcile studies based on planktonic microfossils and on continental data [Peterson et al., 1979; Bush and Colinvaux, 1990; Bonnefille et al., 1992]. Moreover, our estimates are in good agreement with most of the published SST reconstructions derived from the alkenone $\boldsymbol{U}_{37}^{K}$ index in the Atlantic low latitudes [Eglinton et al., 1992; Schneider et al., 1995].

Finally, the better selection of modern analogs leads to a lowering of the error associated with past SST estimates (Table 4). The gain is especially important at middle and high latitudes. The accuracy of salinity reconstructions at these latitudes is thus greatly increased.

In conclusion, our results are characterized by a considerable improvement in core-top SST reconstructions and a lowering of the error associated with SST estimates. We can thus consider that past SSTs reconstructed by RAM are more reliable and precise than SSTs estimated by former methods.

Acknowledgments. We are grateful to $S$. Niebler and A. de Vernal for their help in preparing this manuscript. We also would like to acknowledge B. Lecoat and J. Tessier for runnıng isotopic measurements in Gif. This work has been supported by the Centre National de la Recherche Scientifique and Commıssariat à l'Energie Atomique as well as by the French Programme National de la Dynamique du Climat and the European Reasearch Network program CHRX-CT94-0424. This is contribution 0043 of the LSCE.

\section{References}

Antoine, D., J. M André, and A Morel, Oceanic primary production, 2, Estimation at global scale from satellite (coastal zone color scanner) chlorophyll, Global Btogeochem Cycles, 10, 57-69. 1996.

Bard, E, M Arnold, P Maurice, J Duprat, J. Moyes, and J C Duplessy, Retreat velocity of the North Atlantıc polar front during the last deglaciation determined by ${ }^{14} \mathrm{C}$ accelerator mass spectrometry, Nature, 328, 791-794, 1987

Bartleın, P. J , I C Prentuce, and T Webb, Climatic response surfaces from pollen data for some eastem North American taxa, $J$ Biogeogr, 13, 3557, 1986

Bé, A W. H, An ecologıcal, zoogeographıc and taxonomic review of recent planktonic foraminifera, in Oceantc Mtcropaleontology, vol 1, edtted by A T.S Ramsay, chap. 1. pp $1-100$, Academic, San Diego, Calıf , 1977.

Bonnefille, R, F Chalıé, J Guiot, and A Vincens, Quantitative esumates of full glacial temperatures in equatorial Africa from palynological data, Clim Din., 6, 251-257, 1992.

Bush, M. B, and P. A Colinvaux, A pollen record of a complete glacial cycle from lowland Panama, $J$ Veget Scr., I, 105-118, 1990.

Cayre, O, L Beaufort, and E. Vincent, Paleoproductivity in the equatorial Indian Ocean for the las 260,000 yrs $^{-}$A transfer function based on planktonic foraminifera, Quat. Sct Rev.. in press, 1998

Climate Long-Range Investugation, Mappıng, and Prediction (CLIMAP), Seasonal reconstructions of the Earth's surface at the last glacial maximum, Geol. Soc. of Am Map Chart Ser, MC-36, 1981.

Coplen, T. B., Nomalızation of oxygen and hydrogen ssotope data, Chem Geol., 72, 293-297, 1988

Duplessy, J C., L. Labeyrie, A Juillet-Leclerc, F Martre, J Duprat, and M. Sarnthein, Surface saInity reconstruction of the North Atlantic Ocean during the last glacial maxımum, Oceanol. Acta, 14, 311-324, 1991 .

Duplessy, J C., L. Labeyrie, M. Arnold, M. Paterne, J. Duprat, and T C E. van Weering, Changes in surface salınty of the North Atlantic Ocean dur- ing the last deglaciation, Narure, 358, 485-487, 1992

Eglinton, G, S A. Bradshaw, A Rosell, M Sarnthein, U Pflaumann, and R. Tiedemann, Molecular record of secular sea surface temperature changes on 100-year tumescales for glacial terminations I, II and IV, Nature, 356, 423-426, 1992

Hillaire-Marcel, C , A. de Vernal, G Bılodeau, and G Wu, Isotope stratigraphy, sedimentation rates, deep circulation, and carbonate events in the Labrador Sea during the last $200 \mathrm{ka}$. Can J Earth Scl, 31, 63-89, 1994

Hut, G, Stable isotope reference samples for geochemical and hydrological investigations, $R e$ port to the Director General, Int At Energy Agency, Vienna, 1987.

Hutson, $W$ H, The Agulhas current during the late Pleistocene: Analysis of modern faunal analogs, Science, 207, 64-66, 1979

Imbrie, $J$, and $\mathrm{N}$. G. Kipp, A new micropaleontological method for quantitative paleoclimatology: Application to a late Plesstocene Carıbbean core, in The Late Cenozoic Glacial Ages, edited 
by K K. Turekıan, pp. 71-181, Yale Unıv. Press, New Haven, Conn., 1971

Levitus, S. World Ocean Atlas, Natl. Ocean. Atmos Admin, Washington, D C, 1994

McIntyre, A, W F Ruddiman, K. Karlın, and A. C. Mix, Surface water response of the equatorial Allantic Ocean to orbital forcing, Paleoceanography, 4, 19-55, 1989.

Mıx, A.C, and R.G. Fairbanks, North Atlanuc surface-ocean control of Pleistocene deep-ocean crrculation, Earth Planer. Sct. Lett, 73, 231-243, 1985

Mix, A C., and W F Ruddıman. Structure and timing of the last deglaciation. Oxygen-1sotope evidence, Quat Sct. Rev., 4, 59-108, 1985.

Ortiz, J. D., and A. C Mix, Comparison of ImbneKipp transfer function and modern analog temperature estımates using sediment trap and coretop foraminiferal faunas, Paleoceanography, 12. $175-190,1997$

Overpeck, J. T., T. Webb III, and I C. Prentuce, Quanttative interpretation of fossil pollen spectra: Dissimilarity coefficients and the method of modern analogs, Quat. Res., 23, 87-108, 1985

Peterson, G M., T. Webb III, J E Kutzbach, T van der Hammen, T. A Wymstra, and F A Street,
The continental record of environmental condtions at 18,000 yr B P. An initial evaluation, Quat Res, 12, 47-82, 1979.

Pflaumann, U., J Duprat, C. Pujol, and L Labeyne, SIMMAX: A modern analog technique to deduce Atlantic sea surface temperatures from planktonic foraminifera in deep-sea sediments, $\mathrm{Pa}$ leoceanography, 11, 15-35, 1996.

Prell, W L, The stability of low-lattude sea-surface temperatures: An evaluation of the CLIMAP reconstructuon with emphasis on the posituve SST anomales, Rep. TR025, U S Dep. of Energy, Washington, D C., 1985

Prentice, I. C, Multudimensional scalıng as a research tool in quaternary palynology. A review of theory and methods, Rev Paleobor. Palynol., $31,71-104,1980$

Rosell-Melé, A., G Eglınton, U Pflaumann, and M. Sarnthein, Atlantic core top calibration of the $U^{K}{ }_{7}$ index as a sea-surface palaeotemperature indicator, Geochim Cosmochim. Acta, 59, 30993107, 1995.

Ruddiman, W. F., and A. McIntyre, Ice-age thermal response and climatic role of the surface Atlantic Ocean, Geol. Soc. Am. Bull., 95, 381-396, 1984
Schneider, R. R., P. J. Muller, and G. Ruhland, Late Quaternary surface circulation in the east equatonal South Atlantic: Evidence from alkenone sea surface temperatures, Paleoceanography, 10. 197-219, 1995

Sikes, E L., and L D. Keigwin, Equatorial Atlantic sea surface temperature for the last $30 \mathrm{kyr}$ : A comparison of $U^{K}, \delta^{18} \mathrm{O}$ and foraminiferal assemblages temperature estimates, Paleoceanography, 9, 31-45, 1994.

J -C Dulpessy, L. Labeyne, H Leclaire, and C Waelbroeck, Laboratoire des Sciences du Climat et de l'Environnement, Laboratoire mixte CNRS-CEA, Domane du CNRS, 91198 Gif-sur-Yvette, France (e-mail. clarew@lsce cnrs-gif fr)

J Duprat and M. Labrachene, Departement de Géologie et Océanographıe, CNRS URA 197, Université de Bordeaux I, 33405 Talence, France

J Gurot, Laboratoire de Botanique Historique et Palynologie, CNRS URA 1152, Fac de St-Jérôme, 13397 Marsellle, France

(Received July 31, 1997; revised December 29, 1997; accepted January 6, 1998 ) 